\title{
Tangential Microfiltration of blackberry (Rubus adenotrichus Schltdl.) juice sweetened with stevia (Stevia rebaudiana Bertoni)
}

\author{
Microfiltración tangencial de jugo de mora (Rubus adenotrichus Schltdl.) \\ endulzado con estevia (Stevia rebaudiana Bertoni)
}

César González T. ${ }^{1}$; Fabrice Vaillant B. ${ }^{2}$; María Soledad Tapia G. ${ }^{3}$

\begin{tabular}{ll}
\hline \multicolumn{1}{c}{ ARTICLE DATA } \\
\hline 1 Teacher, Ph.D., Universidad Centroccidental “Lisandro \\
Alvarado", Barquisimeto, Venezuela, cesarcgonzalezt@ \\
gmail.com \\
2 Researcher, Ph.D., Université de Montpellier. Montpellier, \\
France, fabrice.vaillant@cirad.fr \\
3 Teacher, Ph.D., Universidad Central de Venezuela, \\
Caracas, Venezuela, maria.tapia@ciens.ucv.ve
\end{tabular}

Cite: González, C.; Vaillant, F; Tapia, M. (2020). Tangential Microfiltration of blackberry (Rubus adenotrichus Schltdl.) juice sweetened with stevia (Stevia rebaudiana Bertoni). Revista de Ciencias Agrícolas. 36(2): 17-30. https://doi. org/10.22267/rcia.193602.115

Received: October 10, 2017.

Accepted: September 10, 2019.

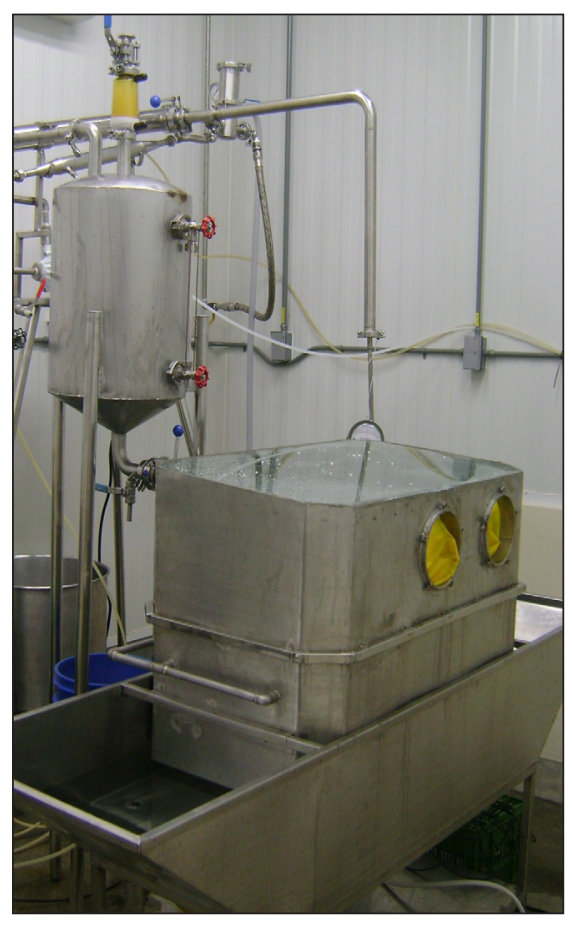

ABSTRACT

The modern consumer values those components that can promote their wellbeing and help them reduce the risk of diseases the use of steviolglucosides as a sweetener in the formulation of foods is promising. The study evaluated the tangential microfiltration for clarification and conservation of blackberry juice sweetened with dried leaves of stevia. Two ceramic membranes were evaluated. The tests were performed at $35^{\circ} \mathrm{C}$ in concentration mode at a constant transmembrane pressure and tangential velocity. The formulation of the juice was defined through sensory evaluation tests. Volume, flow permeate, temperature, and pressure input and output were registered. The results of the variables analyzed in the process, as well as the physicochemical characterization of clarified juice, helped define the operating conditions for draw two formulations of microfiltrated juice, sweetened with stevia or sucrose, and thus evaluate the effectiveness of microfiltration as a conservation treatment. Aciduric microorganisms were quantified; molds and yeasts were carried out in the generated pasteurized samples stored at five different temperatures $\left(5,20,30,37\right.$, and $\left.45^{\circ} \mathrm{C}\right)$. The recovery permeate juice obtained was $84.62 \%$. The permeate Flow (Jp), exhibited higher values at $40 \mathrm{~L} / \mathrm{hm}^{2}$. Also, the concentration of stevioside and rebaudioside $\mathrm{A}$ in the retentate increased with advancing ultrafiltration. A significant variation in color, turbidity, and soluble solids, was observed, unlike the pH. Also, its chemical and microbiological stability is confirmed that allows you to preserve quality during 27 days of storage.

Keywords: conservation; drink; filtration; formulation; membrane; sweetener.

\section{RESUMEN}

Dada la importancia que el consumidor moderno le otorga a aquellos componentes que puedan promover su bienestar y ayudarle a reducir el riesgo de enfermedades, el uso de los esteviolglucósidos como edulcorante en la formulación de alimentos resulta prometedor. El presente estudio evaluó la microfiltración tangencial como tratamiento de clarificación y conservación de un jugo de mora endulzado con hojas deshidratadas de estevia. Se evaluaron dos membranas cerámicas. Los ensayos fueron efectuados a $35^{\circ} \mathrm{C}$ en modo concentración, a una presión transmembranaria y velocidad tangencial constante. La formulación del jugo fue definida a través de pruebas de evaluación sensorial. Se registró el volumen, flujo del permeado, la temperatura y la presión 


\begin{abstract}
de entrada y salida. Los resultados de las variables analizadas y la caracterización fisicoquímica del jugo microfiltrado, permitieron definir las condiciones de operación para elaborar dos formulaciones, uno endulzado con estevia y otro con sacarosa y así evaluar la efectividad de la microfiltración. También se efectuaron recuentos de acidúricos, mohos y levaduras, en las muestras pastaurizadas almacenadas a cinco diferentes temperaturas (5, 20,30, $\left.37 \mathrm{y} 45^{\circ} \mathrm{C}\right)$. El estudio permitió obtener un 84,62\% de recuperación del jugo permeado. El flujo de permeado (Jp), exhibió valores superiores a $40 \mathrm{~L} / \mathrm{hm}^{2}$. La concentración de esteviósido y rebaudiósido A en el retenido aumentó al avanzar la ultrafiltración. Se apreció, una variación de color, turbidez y sólidos solubles, a diferencia del pH. Asimismo se corroboró su estabilidad química y microbiológica al conservar su calidad durante 27 días de almacenamiento.
\end{abstract}

Palabras clave: bebida; conservación; edulcorante; formulación; filtración; membrana.

\section{INTRODUCTION}

Recently patented processes, that membrane technology, are promising substitutes to avoid high costs involved in the application of the new conservation technologies developed. In the filtration process, two or more components of a stream are separated using a membrane called filtration. In this process, the fluids are circulated on semipermeable surfaces that the components of said fluids pass through selectively without experiencing chemical or physical alterations (Solís et al., 2016).

When compared with conventional heat treatments such as pasteurization, it offers numerous advantages, among which stand out, it prevents the loss of nutrients such as vitamin $\mathrm{C}$ and allows to preserve the organoleptic properties of the product. Several studies have evaluated these effects on fruit juices, demonstrating significant differences in the color, smell, and taste of the juices before and after heat treatment (Villareal et al., 2013).

Other advantages of such technology are continuous manufacturing with low energy consumption and the ease of combining with other separation processes (Poletto et al., 2012). According to Benito et al. (2004), microfiltration, ultrafiltration, nanofiltration, reverse osmosis, and osmotic evaporation are included in this category by filtration mechanism. The term microfiltration is used, according to the said author, when particles of diameters 0.1 to $10 \mu \mathrm{m}$ are separated from a solvent and other components of low molecular weight. The separation is by sieve effect and discriminates between the molecules taking into account their dimensions.

Regarding the quality of the products obtained, Vaillant et al. (2004) ensure that they are nutritional, sensory and microbiologically superior to the juices obtained by traditional technologies because membrane filtration is carried out at lower temperatures, which avoids the reduction of thermosensitive components. This technology has demonstrated effectiveness for the extraction and purification of the glycosides present in Stevia rebaudiana, with a high permeate and permeate yield of high quality in terms of color, clarity, total solidity, and purity (Das et al., 2015). Specifically, in tangential microfiltration, the feed flow direction is performed in parallel, in contrast to traditional filtration operations in which the orientation of the feed is perpendicular to the filter medium. This type of microfiltration has allowed to clarify successfully different fruit juices, among which are pineapple (Ananas comosus L. Merr.) (Laorko et al., 2013), raspberry (Rubusidaeus L.) (Vladisavljević et al., 2013) and the mortiño or cranberry (Vaccinium floribundum Kunth) (Tupuna, 2012). Especially, the studies carried out by Montero (2008) and Monteiro (2011) focused on the evaluation of the tangential microfiltration process, during the elaboration of clarified blackberry juices. The latter 
have evaluated the impact on the composition of the permeate obtained concerning the original composition of the juice, emphasizing the content of antioxidant compounds and bioactive properties. The convenience and technological and industrial viability of the application of this technology for the clarification and conservation of blackberry juice can be inferred since it does not significantly affect the reduction of the concentration of components of interest, an aspect that favors its selection for processing of products with greater added value. Based on the above, the present investigation evaluated the application of tangential microfiltration as a conservative treatment of a blackberry juice sweetened with stevia.

\section{MATERIALS AND METHODS}

Fruits of blackberries (Rubus adenotrichusSchltdl) of the variety "wine with thorns", in a state of physiological maturity, were frozen at $-20^{\circ} \mathrm{C}$. Subsequently, they were pressed. They were placed in cloth blankets, inside the CRC brand perforated press cylinder. The pressure and time of the operation were constant. The juice obtained was stored in a freezing chamber at $-20^{\circ} \mathrm{C}$. $\mathrm{PH}$, turbidity, and color determinations were made. Once thawed, they were diluted with drinking water in a 1: 1 ratio (Montero, 2008). Stevia rebaudiana Bertoni leaves of the Morita II variety, produced in the Guayabita sector, Aragua State, Venezuela, were used as a sweetening agent. These were removed from the plants, submerged in water to remove impurities, drained and dehydrated at $50^{\circ} \mathrm{C}$, with final humidity of $8 \%$. Subsequently, they were pulverized in a grinder, Peabody brand, model Pe-mc9103, China. The particle size was regulated in Afnor NF X 11-501 sieve, to particles smaller than or equal to $500 \mu \mathrm{m}$. The proportion of dried leaves of stevia powder was governed by sensory criteria, through acceptability tests carried out previously, by an untrained cupping panel consisting of 100 people. They used an unstructured hedonic scale. It was selected as the concentration that provided the best sensory profile $2.5 \mathrm{~g} / \mathrm{L}$ of pressed blackberry juice. The pressed pulp was previously enzymatically hydrolyzed with NOVOENZYMES Pectinex Ultra AFPL, at a constant temperature and time $\left(35^{\circ} \mathrm{C}\right.$ $\mathrm{x}$ 1hour), with the previous addition of dried dehydrated stevia leaves. The aforementioned treatment was selected in previous trials because of its higher performance.

A tangential microfiltration system was used, consisting of a Zircón alumina ceramic membrane tubular module (SCT France) to obtain the microfiltered juice. The tangential flow was generated by a centrifugal pump, which was fed by the blackberry juice, through a positive displacement pump. The temperature of the fluid inside the system was controlled employing a heat exchanger of tubular configuration. The temperature of the juice in the system was maintained at $35^{\circ} \mathrm{C}$, following the criteria specified by Montero (2008), to avoid decreasing the sensory acceptance of blackberry juice. The temperature and pressure were recorded throughout the operation, through two thermometers and two pressure gauges $\pm 1.0 \mathrm{psi}$ installed at the entrance and exit of the membrane in the line of the retention and for obtaining data for the calculation of the flow of permeate a beaker was placed as a permeate collector on an electronic scale with an accuracy of $0.001 \mathrm{~g}$. The measurement was performed every five minutes. A single mixing phase was established before the microfiltration stage, in which water, blackberry juice, and stevia powder were combined, inputs required to carry out the extraction of steviolglycosides. A factorial design 22 was used, in which two levels of the two variables considered were evaluated, which generated the following treatments: MF blackberry juice sweetened with unpasteurized stevia, MF blackberry juice sweetened with pasteurized stevia, MF blackened 
juice Unpasteurized saccharose and sweetened blackberry MF juice pasteurized saccharose.

\section{Microfiltration of the juice sweetened with} stevia. Two types of ceramic membranes were tested: pore size equal to $10 \mathrm{~nm}, 5 \mathrm{kDa}$, filtration area of $0.33 \mathrm{~m}^{2}$, number of channels 19 , the diameter of channels $4 \mathrm{~mm}$, with active $\mathrm{TiO}_{2}$ layer, manufactured by Pall Corporation, USA and another of $1 \mathrm{kDa}$, filtration area of $0.35 \mathrm{~m}^{2}$, number of channels 23 , the diameter of channels $3.5 \mathrm{~mm}$, with active $\mathrm{TiO}_{2}$ layer, manufactured by TAMI Industries, France. To calculate the permeate flow $\left(\mathrm{J}_{\mathrm{p}}\right)$ the equation was used: ; where: $\mathrm{mp}$, represents the permeate mass, $t$, the time where the value of $\mathrm{mp}$ is taken, and $\mathrm{A}$, the effective filtration area of the membrane. The transmembrane pressure (PTM) was calculated through the equation: where: $\mathrm{P}_{\mathrm{e}}$, represents the inlet pressure of the feed in the membrane and $\mathrm{P}_{\mathrm{s}^{\prime}}$ the outlet pressure of the retained. In each of the tests, the volume and $\mathrm{J}_{\mathrm{P}}$, the temperature, and the inlet and outlet pressure were recorded. For the calculation of the volumetric reduction factor (FRV), the equation was used: , which relates the feed volume $\left(\mathrm{V}_{\mathrm{a}}\right)$ and the hold volume $\left(\mathrm{V}_{\mathrm{r}}\right)$. To ensure the reproducibility of the operation, two microfiltrations were carried out, both in concentration mode, in the system the retention is not removed and it is redirected to the system supply. Both the transmembrane pressure and the tangential speed of the system were constant. A batch of fresh blackberries was processed for two microfilter juice formulations, one sweetened with stevia according to the selected dosage and another sweetened with sucrose. For this, the previously enzymatically hydrolyzed pulp was placed in the feed tank where it was preheated, pumped, and flowed through the MF-UF unit, arranged with the Membralox membrane.

The permeate obtained in the microfiltration studies was subjected to ultrafiltration, in concentration mode. $10 \mathrm{~mL}$ were removed from the permeate and from the retention at constant intervals of time (every 10 minutes), and the concentration of stevioside and rebaudioside A was determined, to assess their contribution to the residual taste indicated by the tasters in the evaluation tests Sensory performed. The total permeate obtained, in each of the two microfiltrations, was packaged under aseptic conditions. The juice was packed in polyethylenealuminum-polyethylene bags. Half of the bags of each formulation were subjected to pasteurization, introducing them into a double jacket kettle heated with steam. Pasteurization conditions were $90^{\circ} \mathrm{C}$ for 30 seconds, conditions secured by a thermocouple in a control sample. After the time, they were removed and submerged in a cold water bath. Each of the four treatments mentioned above were stored under 5 different temperature conditions: 5, 20, 30, 37, and $45^{\circ} \mathrm{C}$, in special cellars prepared for this purpose, with which a total of 20 experimental units were analyzed.

Physicochemical and microbiological evaluation of MF juice samples. The color was determined in Flex Hunterlab color equipment; turbidity with turbidimeter Hash 2100AN, pH with potentiometer Orion model $420 \mathrm{~A}$, and soluble solids with a digital refractometer, Atago. Acidic microorganisms, molds, and yeast counts (Covenin, 1978a; 1978b) were performed in the four treatments. The readings were made on day zero, that is, the same day they were obtained, and after four weeks, stored at the five different temperatures indicated. Similarly, treatment samples were analyzed twice a week, that is, every four days. In each review, both the $\mathrm{pH}$ and the percentage of soluble solids were determined. The quantification of the two main steviolglycosides present in the extracts (stevioside and Rebaudioside A) was performed by liquid chromatography (HPLC). The 1200 series Agilent Technologies chromatograph was used for the measurement, connected to a mass 
spectrograph. The taking of UV-Vis spectra, given the composition of the sample under study, was carried out through a UV-Vis spectrophotometer (Genesys10UV of Thermo). An RP C18 column of $250 \times 4.6 \mathrm{~mm}$ ID was used. The mobile phase introduced to the equipment was composed of acetonitrile: water in 80:20 proportion, respectively. The samples obtained were filtered $0.45 \mu \mathrm{m}$ and analyzed. The chromatograms obtained allowed determining the concentration of the two main steviolglycosides, stevioside and rebaudioside $A$, thanks to references made in the same injections with standard solutions of both glycosides (98\% purity, Sigma-Aldrich, USA). The replicability of the microfiltration tests was corroborated by the Fisher test ( $\mathrm{p} \leq 0.05)$.

\section{RESULTS AND DISCUSSION}

The replicability of the trials was demonstrated, through the Fisher test, there are no significant statistical differences between them $(p=0.250)$. In Figure 1, the similarity of the repetitions in terms of the trajectory experienced by the permeate flow can be visualized, as well as by the FRV in both tests. Under the established conditions, the process was halted, on average, in the 85th minute, when the feeding was exhausted. From the initial 39.28kg of juice, $33.24 \mathrm{~kg}$ of permeate were collected, which represents the $85 \%$ recovery of the permeate juice, coinciding with the values reported by Cozzano (2007), Montero (2008) and Briano (2013), who In all cases, they obtained values above $60 \%$, conditions required for the industrial feasibility of the operation. The evolution of the permeate flow (Jp), as well as the volumetric concentration factor (FRV), for both initial and its replication tests (trials 1 and 2), are presented in Figure 1.

Likewise, the tendency to decrease that the permeate flow exhibits is observed, as microfiltration progresses, due to the accumulation of materials in the vicinity of the membrane in a constant pressure process. This results in the formation of a viscous layer on the surface of it. This phenomenon occurred during membrane filtration, is explained by Vaillant et al. (2001). The flow declines very fast and then stabilizes to finally reach a steady-state stage where the flow does not increase. On the other hand, and concerning FRV, Figure 1 shows its influence on the permeate flow. In juices such as blackberry, as the FRV increases, the permeate flow decreases, as can be seen, FRV values greater than 10, generate flows below 75 L / h.m2.
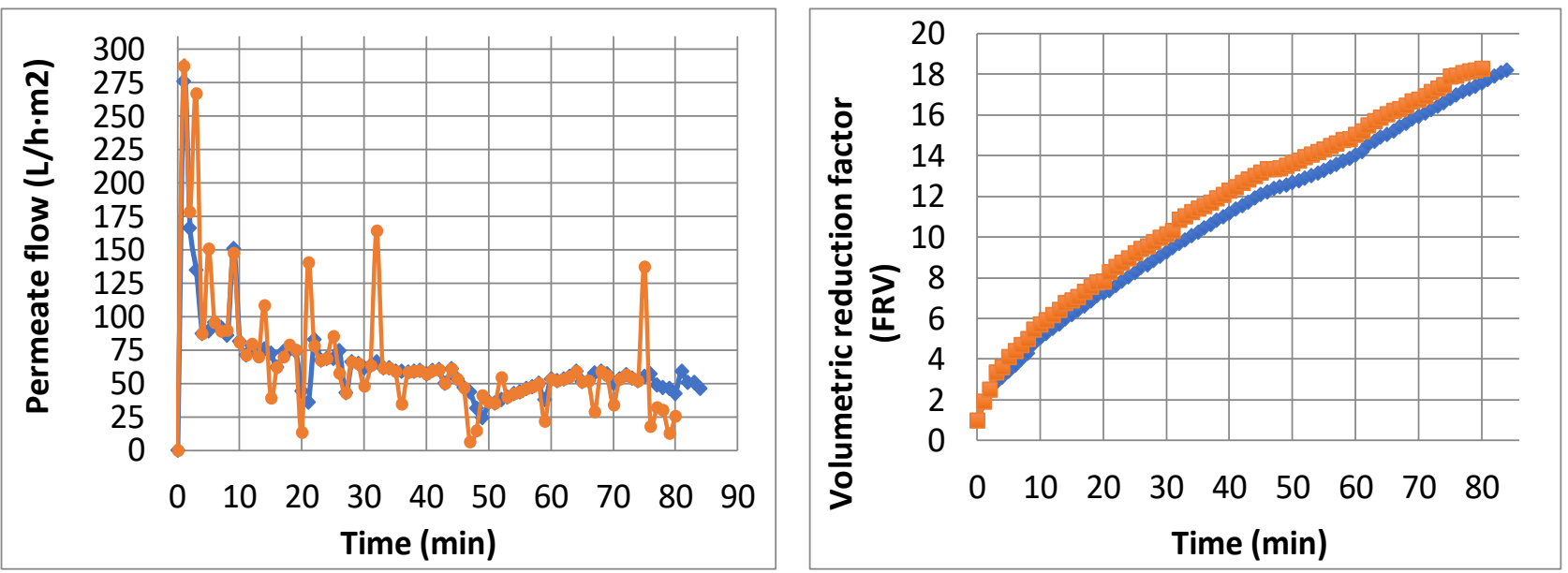

Figure 1. Evolution of permeate flow and volumetric reduction factor during microfiltration tests of blackberry juice sweetened with steviolglycosides. 
In the results a value of FRV is not reached in which the flow remains stable since a constant fraction of the retention is not removed, since the tests were carried out in concentration mode, occurs during microfiltration carried out by other authors with juices from other fruits, parchita (Vaillant et al., 2001), melon (Vaillant et al., 2005), and pineapple (Laorko et al., 2013), where an interval of FRV considered optimal can be established, in The permeate flow is constant. This behavior shown in Figure 1 coincides with the usual performance of permeate flow and the volumetric reduction factor in membrane microfiltration processes. Cassano et al. (2004), characterize the mentioned accelerated reduction of the flow during the first minutes of the operation, which is reduced, in a slight and not constant way. Then, a third stage is displayed (from minute 15 onwards), in which the flow is stabilized by decreasing logarithmically. The authors also indicate a final stage in which the permeate experiences an abrupt fall generated by membrane obstruction, characteristic in filtration processes of viscous fruit pulps. Despite this, the aforementioned flow reduction was not recorded in the study, which ensures that at an FRV of 18, the channels of the membrane have not yet been clogged or significantly blocked.

Figure 1 also highlights the high value of the flows, which are located at values greater than $40 \mathrm{~L} / \mathrm{hm}^{2}$ along the microfiltration. Vaillant et al. (2004) indicate that the minimum flow to guarantee the technical feasibility of the operation should be around 50L/hm2. Similarly, the FRV obtained exceed values of 7 before the 20th minute of the operation, which demonstrates the industrial feasibility to reach yields that exceed $84 \%$. As for the soluble compounds responsible for membrane clogging, Salas (2003) states that they are mainly related to macromolecules solubilized in the extraction of juice, in this case, pectins, as it results in fruit treatments, due to their high clogging power (clogging of membrane pores).
Ultrafiltration of microfiltered blackberry juice sweetened with steviolglycosides. According to the progress of the permeate flow during its ultrafiltration, four fundamental aspects were appreciated, as during its previous microfiltration stage: a) Appreciation of three main phases, a first phase in which an accelerated reduction of the flow, between minutes 0 and 6 of the operation, accompanied by a slight and little constant stage of reduction, which occurs between minute 7 to 23 , ending with a final stage of fluid log reduction, which is stabilized from the 24th minute; b) As the FRV increases, the permeate flow decreases; c) The FRVs registered during the operation exceed values of 5 before the 40th minute of the operation; and d) The remarkable value of permeate flows is highlighted, which is located at values greater than $10 \mathrm{~L} / \mathrm{hm} 2$ throughout the operation, which are acceptable, given the low-performance characteristic of the operation with the type of membranes involved.

These results coincide with those reported in apple juice by Onsekizoglu et al. (2010) and De Bruijn and Bórquez (2006); as well as those indicated by Rai et al. (2005) in Mosambi juice or sweet lemon, Laorko et al. (2013) in pineapple juice and Saha et al. (2007) in cane juice, who reached permeate flows even lower when using juices from other fruits. Despite its value, under the conditions studied, its implementation on an industrial scale, for the generation of a commercial beverage, should be analyzed in greater depth, considering an economic study of the process, to guarantee that the added value granted to the product, be appreciated by the consumer, and justify the high processing costs. The concentrations of the two main steviolglycosides analyzed both in permeate flows and in those retained in the two ultrafiltration tests (Figure 2 and Figure 3), confirm the residual taste, contributed by stevioside. From the aforementioned figures, the following evaluations are generated: a) The concentration of stevioside 
in the retentate has a positive tendency, that is, it increases with the advance of ultrafiltration. This aspect is highly beneficial for the purpose pursued, since retaining a greater amount of stevioside guarantees its absence in the permeate, therefore, less residual flavor. However, the resulting $\mathrm{R}^{2}$ values in the two tests performed are less than 0.7; which does not represent a satisfactory adjustment, which allows us to affirm, based on the tendency exhibited by the concentration of said glycoside, its appreciable increase over time. b) The concentration of rebaudioside $\mathrm{A}$ in the retentate also tends to increase as ultrafiltration progresses. However, the adjustment of its trend has $\mathrm{R}^{2}$ values, slightly higher than 0.7 ; and c) The concentrations of stevioside and rebaudioside $\mathrm{A}$ in the permeate Flow during ultrafiltration remain constant, showing $\mathrm{R}^{2}$ values ranging from 0.06 to 0.31 .

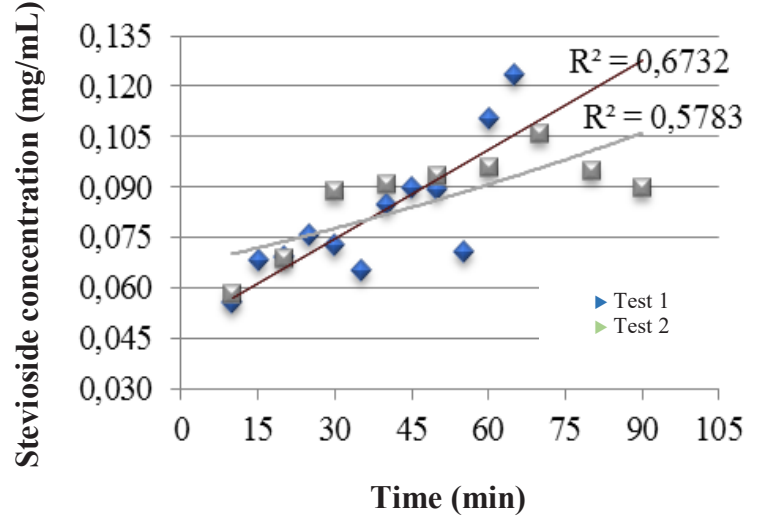

A) Stevioside concentration in the retained

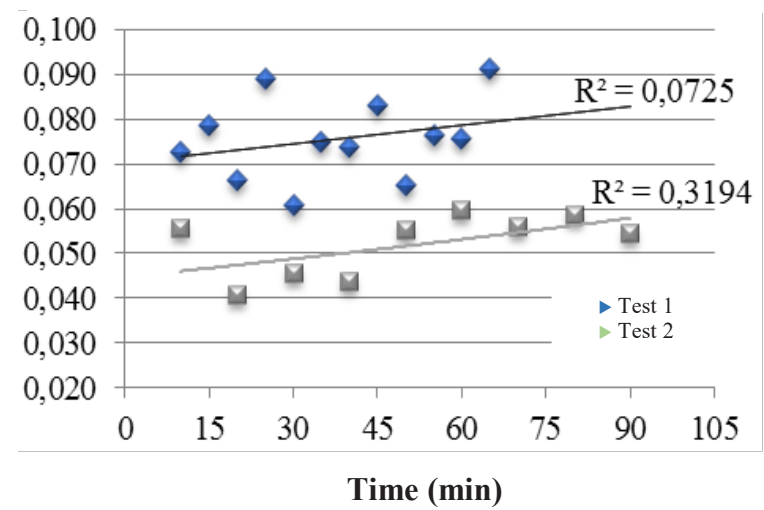

B) Stevioside concentration in the permeate

Figure 2. Stevioside concentration in the flows obtained during the ultrafiltration of sweetenedblackberry juice.

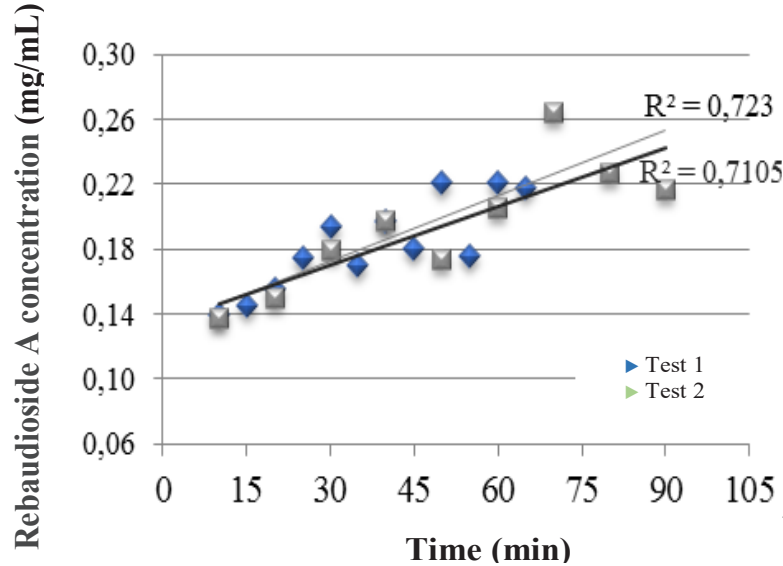

A) Reb A concentration in the retained

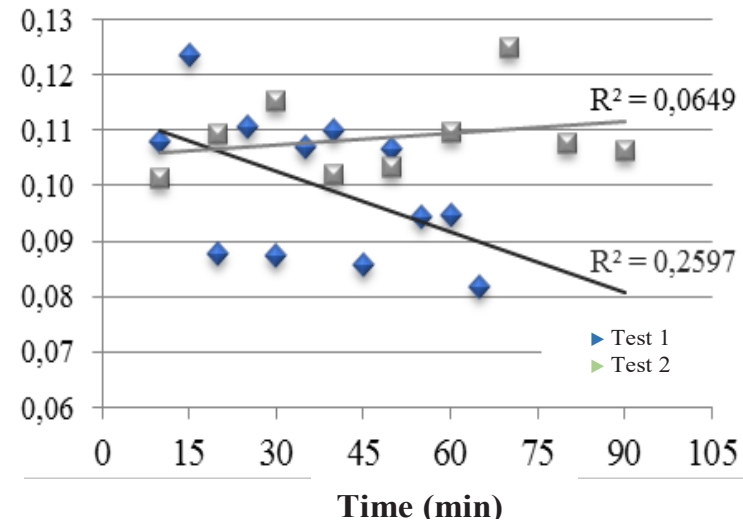

B) Reb A concentration in the permeate

Figure 3. The concentration of rebaudioside $A$ in the flows obtained during the ultrafiltration of blackberry juice sweetened with steviolglycosides. 
These pieces of evidence corroborate that there is no demonstrable effect in reducing the residual flavor of the juice sweetened with steviolglycosides, when applying an ultrafiltration stage. This was ratified, through an informal sensory test carried out by a group of nine members, in which they tasted the four fluids generated in the operations of micro and ultrafiltration of blackberry juice sweetened with stevia, in which, despite the high receptivity of the color of the permeate obtained in the UF expressed by all the individuals, who highlighted its brightness and appearance, mostly preferred the taste of the permeate obtained in the microfiltration stage of the juice. This preference is associated with the greater amount of solids of the microfiltered juice, which provide greater taste and besides, in both cases, micro and ultrafiltration the steviolglucosides analyzed are present, given their solubility and particle size.

Microfiltration and ultrafiltration flows of blackberry juice sweetened with steviolglycosides. The average values obtained in the quantification of the physicochemical parameters in the five treatments are presented in Table 1. Regarding the col- or, the brightness and brightness index (L value), the permeate flows for both micro and ultrafiltration cases, presented, the lowest values fluctuated between 1.96 for UF and 4.78 for MF, which corroborates a lower reflectance of light, characteristic of the studied samples that are predominantly more translucent due to the absence of suspended solids. On the contrary, the retention flows and the pressed blackberry pulp that corresponds to the filtration feed registered higher values, ranging between 9.7 and 11.5.

On the other hand, positive values of the "a" index reflect a lower affinity of the samples due to the green hue. It stands out from the group, the treatment corresponding to the permeate obtained after the UF, since it presented the highest value, that is, closer to the red hue. Concerning the " $b$ " value, all the samples obtained slightly positive values on the respective scale, exhibiting their yellow color closeness. The samples that registered lower values, with greater proximity to the blue tone, were the pulp of pressed blackberry without filtering and the retention obtained in the UF with 1,412 and 1,533, respectively.

Table 1. Physicochemical analysis of the different flows obtained in the MF and UF tests of blackberry juice sweetened with steviolglycosides.

\begin{tabular}{|c|c|c|c|c|c|c|}
\hline \multirow[b]{2}{*}{ Sample } & \multicolumn{3}{|c|}{ Color (CIE Lab) } & \multirow{2}{*}{$\begin{array}{l}\text { Turbidity } \\
\text { (NTU) }\end{array}$} & \multirow[b]{2}{*}{ pH } & \multirow{2}{*}{$\begin{array}{c}\text { Soluble solids } \\
\left({ }^{\circ} \text { Brix }\right)\end{array}$} \\
\hline & $\mathbf{L}$ & a & b & & & \\
\hline Pressed blackberry pulp & $11.55_{\mathrm{a}}$ & $10.33_{\mathrm{e}}$ & $1.41_{i}$ & $513.00_{\mathrm{m}}$ & $3.06_{r}$ & $8.75_{\mathrm{s}}$ \\
\hline Retained MF & 10.47 b & $21.87_{f}$ & $5.34_{j}$ & $2359.00_{n}$ & $2.91_{\mathrm{r}}$ & $4.50_{t}$ \\
\hline Permeated MF & $4.78_{c}$ & $26.47 \mathrm{~g}$ & $6.54_{\mathrm{k}}$ & 32.90 。 & $2.95_{\mathrm{r}}$ & $4.00_{t}$ \\
\hline Retained UF & $9.71_{b}$ & $10.12_{\mathrm{e}}$ & $1.53_{i}$ & $113.00_{p}$ & $2.95_{\mathrm{r}}$ & $6.00_{\text {u }}$ \\
\hline Permeated UF & $1.96_{d}$ & $37.39_{h}$ & $15.06_{1}$ & $0.60_{q}$ & $3.01_{\mathrm{r}}$ & $5.50_{\text {u }}$ \\
\hline
\end{tabular}

Note: Different letters indicate statistical differences according to ANOVA analysis $(\leq 0.05)$ and Tukey test. The expressed values are the result of averaging the values of the 3 samples analyzed, in each of the experimental design conditions (since the test was carried out in triplicate). 
The rest of the samples fluctuated between 5,343 and 6,543, except for the permeate sample obtained after the UF, as is appreciable, which registered the highest value of 15.06. Concerning turbidity, the highest values correspond to the samples that present a higher percentage of suspended solids, in decreasing order, retained of MF with 2359 NTU, caused by the accumulation of insoluble solids during the operation of MF, the pulp of pressed blackberry without MF with 513 NTU, retained from UF with 113 NTU, followed by permeate flows, from MF and UF, with 32.9 and $0.603 \mathrm{NTU}$, the latter with a marked translucency, derived from its composition, completely constituted for soluble solids with molecular weight less than 1000. On the other hand, there were no significant differences between the $\mathrm{pH}$ values of the five samples. The values ranged from 2.91 to 3.06 , which is undoubtedly due to the presence of hydrogen ions, naturally in the initial blackberry juice and which are not removed or separated by any of the two membranes used in the operations of MF and UF. Likewise, statistically significant differences were detected between the concentration of soluble solids present in the samples. As expected, the values of both the retention and permeate flow, products of the UF, reached slightly higher values than those previously obtained in the MF stage.

\section{Analysis of the stability of the juice} formulated during storage. The results of the analyzes of $\mathrm{pH}$ and soluble solids are shown in Figure 4A and Figure 5A, for the case of juice formulated with sucrose and in Figures $4 \mathrm{~B}$ and Figure 5B, for those sweetened with stevia. Similarly, Table 2 describes the total counts of acidic bacteria, molds, and yeasts, presented during storage. By observing Figure 4, a slight rise in $\mathrm{pH}$ can be visualized, experienced by the two formulations during storage, under the five temperature conditions. The values fluctuated in the treatments, during the weekly analyzes performed, between 2.84 and 3.02. The Analysis of Variance, indicated statistically significant differences, with a 99\% confidence level, when analyzing the day variable, with which a variation of the $\mathrm{pH}$ value was determined in both sucrose and stevia formulations during storage. However, for the treatment (sweetening agent) and storage temperature, there were no statistically significant differences. This difference is caused by metabolic compounds secreted by aciduric microorganisms, molds, and yeasts, mainly during their growth. Concerning the total soluble solids values of the treatments, they project, (Figure 5), a decrease in both formulations, more pronounced in the samples formulated with sucrose. In the latter case, the samples stored at 30 and $37^{\circ} \mathrm{C}$, experienced the highest decrease, reaching values of $6^{\circ}$ Brix, four percentage points lower than their initial value since they were formulated up to $10^{\circ}$ Brix, which was corroborated statistically The analysis did not show significant differences between the pasteurized and unpasteurized samples.

In Figure 5B, samples made with stevia did not show an appreciable reduction. Because of its high sweetening power, only the addition of a small amount of dried powdered leaves was required in treatments formulated with stevia, which did not significantly influence the percentage of soluble solids of blackberry juice during its preparation. The formulated juice registered an average of $5.2^{\circ} \mathrm{Brix}$, on day zero that is, the day of its elaboration, and at the end of its storage, after 27 days, the samples conserved at five different temperatures, recorded valuesbetween 5 and $5.1^{\circ}$ Brix. 


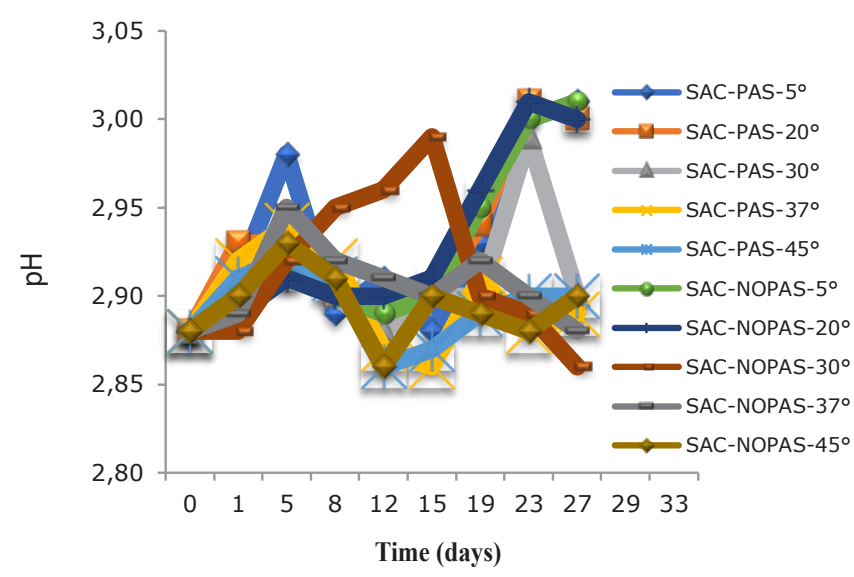

A) MF blackberry juice formulate with saccharose

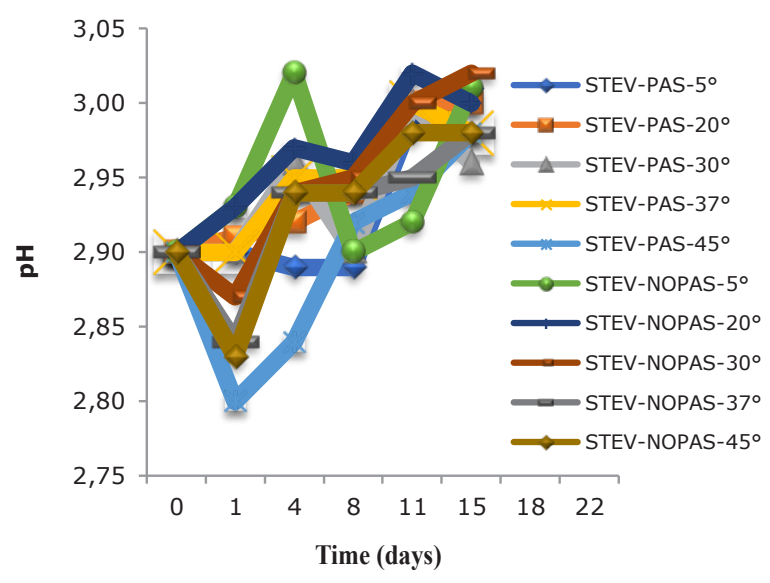

B) MF blackberry juice formulate with stevia

Note: abbreviations summarized in the figure: SAC: juices sweetened with saccharose, STV: juices sweetened with stevia, PAS: sometimes pasteurization samples, NOPAS: unpasteurized juice samples.

Figure 4. pH variation of microfiltered blackberry juice treatments.

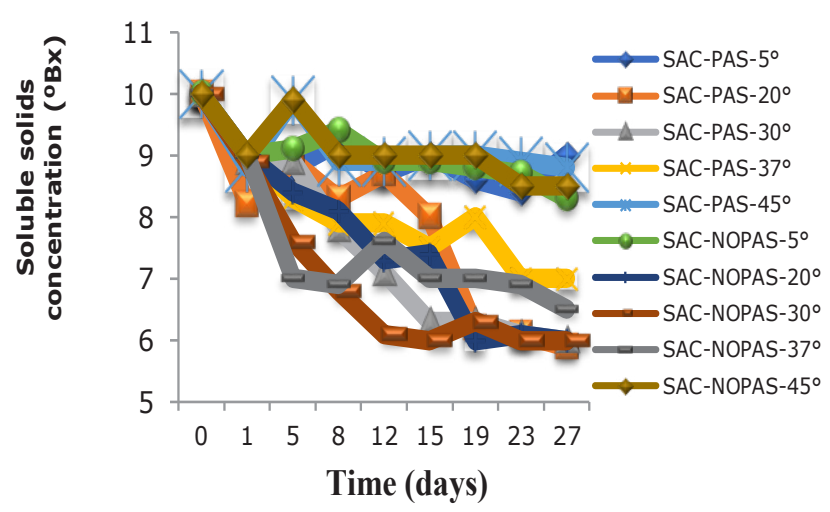

A) MF blackberry juice formulate with saccharose

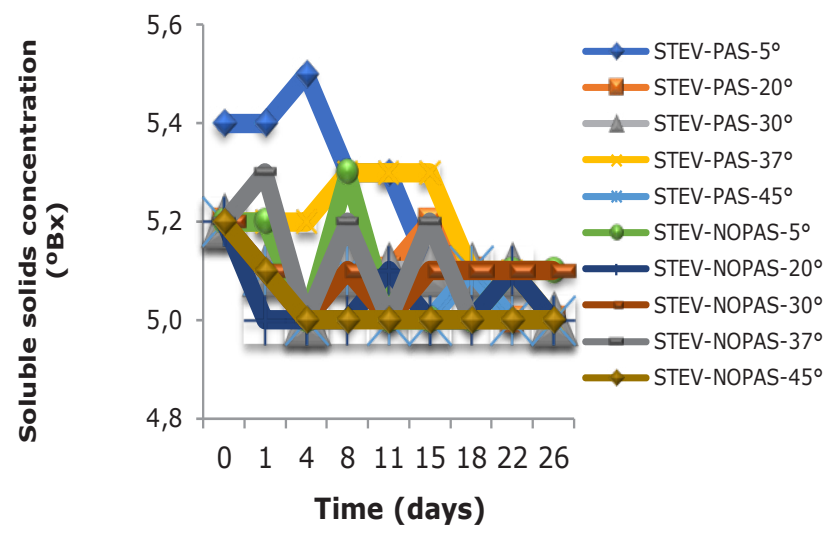

B) MF blackberry juice formulate with stevia

Note: abbreviations summarized in the figure: SAC: juices sweetened with saccharose, STV: juices sweetened with stevia, PAS: sometimes pasteurization samples, NOPAS: unpasteurized juice samples.

Figure 5. Total soluble solids variation experienced by microfiltered blackberry juice treatments.

When comparing the values, significant differences in temperature were revealed. In other words, only differences in the values of total soluble solids are observed in the sample preserved at $5^{\circ} \mathrm{C}$ concerning the others, without obtaining appreciable differences in the treatment (pasteurization), nor in the day of analysis effect.
Similar results were achieved by Nandi et al. (2009) who found that the same properties (SST and $\mathrm{pH}$ ) were not affected in a juice of mosambi (sweet lemon) after microfiltration. In this order of ideas, Briano (2013) reported very similar results, when studying a blackberry concentrate, of the same variety, obtained by the same microfiltration 
system. When evaluating the stability of the retentate, an increase in the $\mathrm{pH}$ value close to 35\% was observed, from 2.14 to 2.89 after two weeks of storage and a decrease in the concentration of soluble solids of $36 \%$. On the other hand, the microbiological behavior of the formulated samples is presented in Table 2 . The count of acidic microorganisms, molds, and yeasts is detailed, at day zero and after 8 and 27 days, during the storage of the samples at $5^{\circ} \mathrm{C}$. Unpasteurized samples formulated with sucrose, showed low microbiological counts since obtaining (zero-day), shows a slight but constant growth during the first eight days of storage, and values below $180 \mathrm{CFU} / \mathrm{mL}$ of acidic bacteria. Similarly, low growth of expansive filamentous fungi was observed in the mentioned samples. The count was kept below 1 x $10^{2} \mathrm{CFU} / \mathrm{mL}$, even on day 27 of storage.

Table 2. Counts obtained in microbiological analyzes performed on samples of microfiltered blackberry juice during storage.

\begin{tabular}{|c|c|c|c|c|c|c|c|c|c|}
\hline \multirow[t]{2}{*}{ Sample } & \multicolumn{3}{|c|}{$\begin{array}{l}\text { Microorganism count aciduric } \\
\text { microorganism }(\mathrm{CFU} / \mathrm{mL})\end{array}$} & \multicolumn{3}{|c|}{$\begin{array}{l}\text { Mold count } \\
\text { (CFU/mL) }\end{array}$} & \multicolumn{3}{|c|}{$\begin{array}{l}\text { Yeast count } \\
\text { (CFU/mL) }\end{array}$} \\
\hline & Day 0 & Day 8 & Day 27 & Day 0 & Day 8 & Day 27 & Day 0 & Day 8 & Day 27 \\
\hline $\begin{array}{l}\text { Sweetened with } \\
\text { sucrose and } \\
\text { pasteurized }\end{array}$ & $<10$ & $<10$ & $<10$ & $<10$ & 12 & $<10$ & $<10$ & $<10$ & $<10$ \\
\hline $\begin{array}{l}\text { Sweetened with } \\
\text { sucrose } \\
\text { unpasteurized }\end{array}$ & $<10$ & 177 & 533 & $<10$ & $<10$ & 37 & $<10$ & 106 & 663 \\
\hline $\begin{array}{l}\text { Sweetened } \\
\text { with stevia and } \\
\text { pasteurized }\end{array}$ & $<10$ & $<10$ & $<10$ & $<10$ & $<10$ & $<10$ & $<10$ & $<10$ & $<10$ \\
\hline $\begin{array}{l}\text { Sweetened with } \\
\text { stevia } \\
\text { unpasteurized }\end{array}$ & $<10$ & $<10$ & $<10$ & $<10$ & $<10$ & $<10$ & $<10$ & $<10$ & $<10$ \\
\hline
\end{tabular}

On the other hand, the growth of yeasts in the treatments sweetened with sucrose, without pasteurization, presented counts less than $1 \times 10^{1}$, after its elaboration, and less than $1 \times 10^{3}$ after 8 and 27 days of storage at $5^{\circ} \mathrm{C}$. This shows contamination during the sample packaging process, since the juices under this same formulation that were subjected to a pasteurization stage, did not register microbial counts. Similar results were achieved by Matta et al. (2004), when obtaining a refined pulp of acerola (sequestration), subjected to an enzymatic stage, followed by clarification by MF. The product obtained showed low microbiological counts, sufficient for the preservation of the juice. Such behavior is explained by Tapia et al. (2008), who point out that due to the chemical and / or enzymatic hydrolysis experienced by sucrose, it is fragmented into its respective monomers: fructose and glucose. Hydrolysis modifies the aw of fruit juices, due to the high capacity of fructose and glucose to reduce aw, thus increasing the effect of this barrier on microbial growth. In the case of the sample studied, the hydrolysis of sucrose was due to the low $\mathrm{pH}$ of the blackberry pulp. The samples that underwent heat treatment after microfiltration did not show microbial counts. 
The three measurements made, in the three established conditions, aciduric microorganisms, molds and yeasts, registered values lower than $1 \mathrm{x}$ $10^{1} \mathrm{CFU}$, this is due to the suppressive effect of both microorganisms and enzymes that the temperature in the time used. In contrast, the samples formulated with stevia, whether or not subjected to pasteurization, did not show a count, on the three occasions in which the counts were made, day zero, 8 and 27, they recorded values below the minimum dilution, that is, counts less than $1 \mathrm{x}$ $100 \mathrm{CFU} / \mathrm{mL}$. This confirms the antimicrobial effect of stevia, by inhibiting microbial development in microfiltered blackberry juice. Such antibaterial effects have been widely reported in the Puri et al. (2012), based on studies carried out by different authors, which have corroborated the stevia inhibitory activity against the growth of some bacteria and other infectious organisms.

\section{CONCLUSIONS}

Concerning the microfiltration study carried out, the different stages established allowed obtaining a high percentage of recovery of the permeate juice. The tendency to decrease that the permeate flow exhibits is observed, as microfiltration progresses, and the permeate flow decrease as the FRV increases. The increase in FRV generates a decrease in permeate flow, as well as a remarkable value of permeate flows obtained throughout the operation. The concentration of stevioside and rebaudioside $\mathrm{A}$ in the retentate increases with the advance of ultrafiltration and there is no demonstrable effect in reducing the unpleasant taste of the juice sweetened with steviolglycosides. There was a significant variation in color (with a decrease in the value $L$ and $b$, and an increase in the value a), lower turbidity in the UF and higher soluble solids in the UF. The juice formulated during storage maintained its chemical and microbiological stability by recording $\mathrm{pH}$ values, soluble solids, and microbial counts that allow it to retain its quality for at least 27 days of storage under refrigeration conditions. This aspect added to the favorable organoleptic properties, and the nutritional potential of the formulated juice, suggests the technical feasibility under the conditions described, for use on an industrial scale.

\section{ACKNOWLEDGMENTS}

The authors thank the National Center for Food Science and Technology (CITA), as well as the School of Food Technology of the University of Costa Rica for facilitating its facilities for the development of research.

Conflict of interest: The authors declare that there is no conflict of interest.

\section{BIBLIOGRAPHIC REFERENCES}

Benito, J.; Conesa, A.; Rodríguez, M. (2004). Membranas cerámicas. Tipos, métodos de obtención y caracterización. Bol. Soc. Esp. Ceram. V. 43 (5):829842.

Briano, L. (2013). Production of ellagitannins concentrate by UF-NF from tropical highland blackberries. Recovered from https://run.unl.pt/ bitstream/10362/10420/1/Briano_ 2013.pdf

Cozzano, A.; Jiao, B.; Drioli, E. (2004).Production of concentrated kiwifruit juice by integrated membrane process. Food res int. 37(2):139-148. doi: 10.1016/j.foodres.2003.08.009

COVENIN - Comisión Venezolana de Normas Industriales. (1978a). Método para el recuento de aerobios mesófilos, Norma № 902. Caracas: FONDONORMA.

COVENIN - Comisión Venezolana de Normas Industriales. (1978b). Método para el recuento de mohos y levaduras, Norma № 1337. Caracas: FONDONORMA. 
CozZANO, S. (2007). Impacto del proceso de microfiltración tangencial sobre el valor de la mora (Rubusspp) como alimento funcional. Costa Rica: Universidad de Costa Rica.

Das, A.; Paul, D.; Golder, A.; Das, C. (2015). Separation of Rebaudioside-A from stevia extract: membrane selection, assessment of permeate quality, and fouling behavior in laminar flow regime. Separation and Purification Technology. 144: 8-15.

De Bruijn, J.; Bórquez, R. (2006). Analysis of the fouling mechanisms during cross-flow ultrafiltration of apple juice. Food sci tech. 39(8):861-871.

Laorko, A.; Tongchitpakdee, S.; Youravong, W. (2013). Storage quality of pineapple juice non-thermally pasteurized and clarified by microfiltration. J food eng. 116(2):554-561. doi: 10.1016/j. jfoodeng.2012.12.033

Matta, V. M.; Moretti, R. H.; Cabral, L. M. (2004). Microfiltration and reverse osmosis for clarification and concentration of acerola juice. $J$ Food Eng. 61(3):477-482. doi: 10.1016/S02608774(03)00154-7

Monteiro, F. S.; Viotto, L. A.; Cabral, L. M. C. (2011). Evaluation of anthocyanin content on blackberryjuice (Rubus spp.) processed by microfiltration. Athens, Grecia: Embrapa Agroindústria de Alimentos-Artigo em anais de congresso (ALICE).

Montero, M. (2008). Estudio del proceso para la elaboración de jugo clarificado de mora por microfiltración tangencial. Costa Rica: Universidad de Costa Rica.

Nandi, B. K.; Das, B.; Uppaluri, R.; Purkait, M. K. (2009). Microfiltration of mosambi juice using low-cost ceramic membrane. J Food Eng. 95(4):597-605.doi: 10.1016/j.jfoodeng.2009.06.024

Onsekizoglu, P.; Bahceci, K. S.; Acar, M. J. (2010). Clarification and the concentration of apple juice using membrane processes: A comparative quality assessment. J Membrane Sci. 352(1):160-165. doi:10.1016/j.memsci. 2010.02.004

Poletto, P.; Duarte, J.; Lunkes, M. S.; Dos Santos, V.; Zeni, M.; Meireles, C. S.; Bottino, A. (2012). Avaliação das características de transporte em membranas de poliamida 66 preparadas com diferentes solventes.
Polimery-w. 22(3):273-277. doi: 10.1590/S010414282012005000041

Puri, M.; Sharma, D.; Barrow, C. J.; Tiwary, A. K. (2012). Optimisation of novel method for the extraction of steviosides from Stevia rebaudiana leaves. Food Chem. 132(3):1113-1120. doi: 10.1016/j. foodchem.2011.11.063

Rai, P.; Majumdar, G. C.; Dasgupta, S.; De, S. (2005). Understanding ultrafiltration performance with mosambi juice in an unstirred batch cell. $J$ Food Process Eng. 28(2): 166-180. doi: 10.1111/j.17454530.2005.00399.x

Saha, N. K.; Balakrishnan, M.; Ulbricht, M. (2007). Sugarcane juice ultrafiltration: FTIR and SEM analysis of polysaccharide fouling. $J$ Membrane Sci. 306(1):287-297. doi: 10.1016/j. memsci.2007.09.006

Salas, R. (2003). Estudio del proceso de clarificación de jugo de banano mediante microfiltración tangencial. Recovered fromhttp:// repositorio.sibdi.ucr.ac.cr: 8080 /jspui / bitstream/123456789/2516/1/28855.pdf

Solís, C.; Vélez, C.; Ramírez, J. S. (2016). Tecnología de membranas: desarrollo histórico. Entre Ciencia $e$ Ingeniería. 19:89-98.

Tapia, M. S.; Alzamora, S. M.; Chirife, J. (2008). Effects of Water Activity $\left(\mathrm{a}_{\mathrm{w}}\right)$ on Microbial Stability: As a Hurdle in Food Preservation, pp 239. En: BarbosaCánovas, G. V; Fontana, A.J.; Schmidt S.J. \& Labuza, T.P. Water activity in foods. Segunda edición. Iowa, USA: IFT Press and Blackwell Publishing.

Tupuna, S. D. (2012). Obtención de jugo clarificado concentrado de mortiño (vaccinium floribundum Kunth) mediante el uso de tecnología de membrana. Recovered fromhttp://bibdigital.epn.edu.ec/ bitstream/15000/4947/1/CD-4485.pdf

Vaillant, F.; Millan, A.; Dornier, M.; Decloux, M.; Reynes, M. (2001). Strategy for economical optimisation of the clarification of pulpy fruit juices using crossflow microfiltration. J Food Eng. 48(1):83-90. doi: 10.1016/S0260-8774(00)00152-7

Vaillant, F., Perez, A. M.; Viquez, F. (2004). Microfiltración tangencial: Una alternativa innovadora para la transformación de frutas tropicales. La Alimentación 
Latinoamericana. 252:38-46. doi: $10.1016 / j$. ifset.2004.11.004

Vaillant, F.; Cisse, M.; Chaverri, M.; Perez, A.; Dornier, M.; Viquez, F.; Dhuique-Mayer, C. (2005). Clarification and concentration of melon juice using membrane processes. Innov Food Sci Emerg. 6(2):213-220. doi: 10.1016/j.ifset.2004.11.004

Villareal, Y.; Mejía, F.; Osorio, 0.; Cerón, F. A. (2013). Efecto de pasteurización sobre características sensoriales y contenido de vitamina $C$ en jugos de frutas. Biotecnologia en el Sector Agropecuario y Agroindustrial. 11(2): 66-75.

Vladisavljević, G. T.; Vukosavljević, P.; Veljović, M. S. (2013). Clarification of red raspberry juice using microfiltration with gas backwashing: A viable strategy to maximize permeate flux and minimize a loss of anthocyanins. Food Bioproducts Process. 91(4):473-480. doi: 10.1016/j.fbp.2013.05.004 